\title{
Expansion of human sexuality in cyberspace
}

\section{KEYWORDS}

sex, sexuality, Internet, date, couple

\begin{abstract}
Nymś-Górna Agnieszka, Expansion of human sexuality into cyberspace. Culture - Society - Education no 2(16) 2019, Poznań 2019, pp. 279-288, Adam Mickiewicz University Press. ISSN 2300-0422. DOI 10.14746/kse.2019.16.18.

One of the key aspects of human life is sexuality. Like other areas of human life, it is constantly changing. However, the technological revolution of recent years has been particularly influential. The aim of this article is to present the progressive revolution of human sexuality in the context of the development of new technologies.
\end{abstract}

In the broadly understood culture, human sexuality and gender are exposed at any time, all the more so if we focus on cyberspace. The Internet is a place that exudes sexuality and carnality, where sex is omnipresent, even permeating into the real life of Internet users.

Within a broad spectrum of culture, two basic concepts can be distinguished, namely desexualisation and sexualisation of culture. Both of these terms have, over time, dominated the consciousness of the society to a varying extent. The first one led to the removal of all elements that could be associated with sex and human sexuality - even carnality - from everyday life, which applied both to interpersonal relations and to material things, as well as ritualised patterns of behaviour. The aim of desexualisation of culture was to create human beings who would be free from sex drive (although only to a certain extent, taking into account common sense and the natural instincts of the human body). Sexualisation of culture, on

* ORCID https://orcid.org/0000-0001-5538-1953. She receives scholarship of the Adam Mickiewicz University Foundation 2019/2020. 
the other hand, results from excessive occurrence of sexual motifs and themes in culture. Objects and everyday life activities, which have not been previously linked to sex, now gained a second, sexualised meaning. The danger associated with this is the subordination (to varying degrees) of human identity to the sexual sphere (Melosik, 2010).

Media and their messages are the most recent manifestations of modernity, since they are connected with the metamorphosis of the cultural habitus, the creation of thought constructs and cognitive patterns. They influence the imagination and sensitivity of the audience of their content. In the media, sexuality is most often perceived from three diverse standpoints - as a problem, as a source of enjoyment and as a commodity (Klimczyk, 2008).

The phenomenon of showgirls, which emerged relatively recently, constitutes an example of all three of these standpoints. Showgirls combine two aspects of the service sector - prostitution and pornography, since their offering comprises exposing themselves and being watched thanks to their webcams. This phenomenon concerns both young girls, as well as mature women. Their main aim is to obtain specific material resources by exploiting sexual needs and desires of their customers (Papież, 2004). This phenomenon can be perceived (depending on individual views) as a problem, source of enjoyment or commodity. Pedagogues and therapists can perceive it as a problem, since this phenomenon can be particularly dangerous for young people, as it can have a negative impact on their actual image of sexuality. It can also serve as a source of pleasure and enjoyment for customers using the services offered by these girls and women. On the other hand, they can be also treated as goods and commodities by customers themselves and by people espousing strongly liberal views, believing that this kind of activity is just like any other types of services available on the market.

Sexual needs and desires are inextricably linked with touch. In addition, touch is a part of everyday life all in itself, not only as something related to sexuality, but also as a form of non-verbal communication. It evokes various emotions, both positive and negative. Apart from the importance of the form of touch itself, the person touching and the body part that is touched are just as important. The genesis of preferences connected with sensory sensations can be sought in childhood. Touch deprivation at that stage of human life may be associated with serious developmental deficits, manifesting itself in every sphere of functioning, including behavioural disorders. In addition, when considering the issue of touch, another noteworthy aspect is its impact on self-esteem. This is a key issue in the context of the analysis of the basis of human sexuality. It is important to ensure an appropriate level of self-esteem, because both too low and too high a level of self-esteem 
negatively affects human functioning. Approval of touch is related to the general self-esteem, as well as one's appreciation of one's own body, since touch itself is very important for the human being and absorbs their "self," which definitely does have an impact in terms of self-perception (Janda-Dębek, Kuczyńska, 2006). It is obvious that the media prevent direct contact, including touch, and their users deal with contact mediated by the media. This can be linked to the impoverishment of not only sensual but also emotional and social experiences.

As far as research into sensory deprivation is concerned, such studies are not done particularly frequently, mainly for ethical reasons. One of the experiments was conducted on volunteer students, who were deprived of access to visual, auditory and tactile stimuli. None of the volunteers decided to continue the experiment for more than a few days. Everyone, on the other hand, experienced various thought disorders, even hallucinations. In turn, an experiment on chimpanzees proved that touch deprivation led them do display a decreased efficiency in solving behavioural tests, and they were unable to understand touch signals, which chimpanzees use to communicate naturally. In addition, Carla J. Shatz claimed that the proper development of the child requires providing them with visual, auditory and tactile stimuli. She stated that children who spend the first year of their lives lying mainly in their beds do not sit at the age of two and only $15 \%$ of them start walking at the age of three (Kozłowska, 1993).

As a result of the changes in Internet communication brought about by recent years, a new category has been identified - the culture of exposing oneself, which showcases the metamorphosis of eroticism in forms of cultural expression. It concerns a group of people whose members are divided into two categories. One of them willingly looks at other people's lives, browsing the Internet for hours to follow their favourite online buddies. The second group of people willingly shares their personal experiences, leaving no area of their lives private - including their erotic life, which often enjoys the greatest popularity. Images presenting human sexuality have a strong impact on human psyche, and excessive exposure of the body ceases to evoke any negative connotations. For this reason, almost no one feels appalled anymore; only a small group of people accidentally exposed to such content feel embarrassed, but their opposition is not taken into account. (McNair, 2001) This phenomenon is also connected with the pornographisation of culture, which concerns deeply rooting pornography in culture as its integral element (Bieńko, 2011). Pornographisation of culture results in the fact that even people who do not necessarily want to have direct contact with pornographic materials are forced to experience it by the current cultural reality, in which pornography appears so often that people are unable to avoid it. 
Treating pornographic sites in the same manner as websites offering other kinds of content indicates the better perception of pornography in the collective consciousness of Internet users, as evidenced by the positioning of pornographic sites on the list of 500 most popular websites around the world (compiled by Alexa. com administrators). It turned out that at the time of the ranking (2010), Pornhub, found at www.pornhub.com (ranked 56th) overtook the CNN website at www. cnn.com website in the ranking (Babecki, 2010). As of now, Pornhub.com is now 32nd, ahead of LinkedIn - a business social network found at www.linkedin.com [retrieved on 23.04.2018].

These phenomena are linked by "sexting" and "toothing". The first term means sending photos (both presenting oneself, as well as other people), which constitute explicit sexual content, including exposed genitals. The second, means arranging meetings with unknown people anonymously, with express purpose of engaging in sexual contact. Both sexting and toothing are currently treated as a kind of sex game (Beisert, 2012), and as a result, most people who undertake these activities treat them as non-committal and not involving many emotions.

It is also worth mentioning erotomania, or in other words, sexual addiction. In the context of the subject of this paper, this issue becomes particularly relevant when it takes the form of an addiction satisfied thanks to the Internet. One of the types of sex addicts, covered in their rich typology, is a type of Internet-obsessed sex addict (Pospiszyl, 2008). Such person feels compelled to browse the web in search of satisfactory sexual experiences. Such person regularly participates in sex chat rooms, as well as browses all discussion forums that deal with broadly understood sexuality. In addition, they also develop a list of their online lovers on their computers. Observers may find it hard to tell whether a person has such a high sexual drive, or dealing in an addiction, satisfied in the online world (Pospiszyl, 2008). However, this is an interesting way to characterise people struggling with this problem.

There are no statistics on sex addiction in Poland. In the United States, Patrick Carnes made an attempt to estimate the number of people suffering from this problem. According to him, $3 \%$ to $6 \%$ of Americans are sex addicts, mostly men, with women making up about $20 \%$ of the group (Osipczuk, Hajek, 2002).

Sex addiction can be linked to new technological advances that make it easier to achieve full sexual satisfaction, which are also used by people who are not addicted, but living in long-distance or on-line relationships. Such solutions include tele-immersion - a system of cameras which enable imitating multi-dimensional experiences, orgasmatron (a device which emits brain waves analogous to these which are induced naturally during an orgasm), tele-vibrators (vibrators controlled using 
a computer or a smartphone), and specially constructed sensory suits equipped with sensors which imitate a direct contact of cyber lovers (Nowosielski, 2010).

The willingness to seek increasingly modern technological solutions, as well as bolder types of sexual contact can be traced back to the sexualisation of childhood. This is another new concept that has become popular in real life, permeating into academic debates. Young people are becoming more and more active in roles that were previously reserved only for adults. In some circumstances, they might become insensitive to the needs of their partners, focusing only on the carnal experiences. Since intimacy began to be commercialised (and linked with business), young people, who are still developing sexually, become victims of culture. On the other hand, the older generation was forced to confront progressive technological changes, which forced them to face numerous changes concerning morality, as well as over-representation of the subject of human sexuality in culture. In the media, sex becomes available regardless of one's age (Wójtewicz, 2009).

We also need to consider the very definition of cybersex as a concept. First of all, it is an extremely broad term, covering all kinds of sexual activities that can be carried out on the Internet. This includes, for example, searching for pornographic images on websites and using them to attain sexual satisfaction, describing one's own sexual fantasies combined with masturbation, which can be carried out online with one's partner, while exchanging current experiences and accompanying emotions (Waszyńska, 2015).

The current instant culture, the main dimensions of which are instantaneity and pleasure, offers the triad of fast food, fast sex and fast car. Fast sex can be defined as obtaining immediate (but short-lived) sexual satisfaction, as well as the lack of emotional involvement (Melosik, 2013). Cybersex and cyberflirting fit perfectly into this concept. Of course, not every case of cybersex needs to be necessarily associated only with hedonistic attitude of partners, who exclude emotions in the sexual act. There are also online relationships, which also involve cybersex, based on a deep emotional bonds.

In 2002, typing "sex" into the search engine returned 201,000,000 results. In 2007, the same search would return 412,000,000 results, including 1,520,000 Polish ones. In May 2013, there were already 2,910,000,000 such pages (Waszyńska, 2015). In May 2017, 3,170,000,000 results appeared upon searching the phrase in question, including 3,920,000 Polish ones [retrieved on 27.05.2017]. The above figures show how vast of an area of the Web is devoted to sex and how rapidly it is growing.

In order to show the scale of this phenomenon, it is worth bringing up a number of examples referring to phrases that are equally important for humans. In 
April 2013 the number of results for search terms: love, health, development, life and violence, was respectively: 50,900,000 (love), 71,000,000 (health), 49,000,000 (development), 125,000,000 (life), 59,100,000 (violence). Thus, as we can see, these are much smaller numbers (Waszyńska, 2015).

Despite the dangers and risks of over-representation of sexuality and sexuality on the Internet, there is also an opportunity for those who have managed to create happy, long-term relationships thanks to it. Contemporary people like to experiment; therefore, they do not hesitate to try and find a partner on the Internet, and seamless access to this medium encourages them to try, take up new challenges and use technological innovations.

The search for online sexual experiences (and more) sometimes results in the formation of relationships in cyberspace. There is no doubt that online relationships are very peculiar in nature. Subject literature characterises these relationships, pointing out a number of their specific features (Waszyńska, 2015):

1. Close bond over a long distance

Distance is becoming less and less important in terms of meeting the need for closeness. People who live at a significant (physical) distance can be perceived as closer than those who sit in a room next door. It is obvious that this feeling is extremely subjective, but it takes on a completely different meaning in the context of long-distance relationships, where the possibility of physical contact is limited.

2. Distance and directness

Due to physical distance, partners become bolder in their relationship. They are not ashamed to talk about embarrassing matters, they become more tolerant, direct and - above all - open (including towards creating a deeper relationship and sexual experiments).

3. Poor and rich communication

Due to the smaller number of available communication strategies, the partners are able to provide a lot of information, while adapting to such situations. Additionally, they use emoticons to try and convey their emotions. They are perfectly capable of presenting reality and sharing their everyday life with their partner.

4. Anonymity and openness

Anonymity means being more open to sharing one's privacy. Partners seem to be more authentic, natural and friendly towards each other, which is conducive to the feeling of closeness. They become more involved in the relationship.

5. Honesty and deceit

On the Internet, people can freely create their own identity, present their selves - including in the area of sexuality, as well as their social status. Falsehood and deceit are commonly believed to be negative phenomena, but in virtual reality 
it may be met with a slightly different approach. Due to the fact that honesty can sometimes be painful, the meaning of deceit can be less pejorative, closer to a kind of a dream.

6. Continuity and discontinuity

This element is often perceived in a very specific manner. The relationship is not continuous, because communication itself does not have a regular and continuous form. On the other hand, continuity occurs in an emotional sense, because the partners constantly think about each other (despite performing a number of other activities). In addition, they are open to contact at any time.

7. Low physical and high mental investment

The search for online love requires lower financial outlay, and as such it is much more viable (from a pragmatic standpoint). Maintaining an online relationship also seems to be cheaper. On the other hand, emotional investment should be the same as in real world, if the partners are considering full commitment to the relationship and want it to last.

8. Social activities carried out alone

While performing various social activities, such as talking to one's partner online, people are actually alone. This also concerns experiencing various emotions, including those connected with sexual and intimate experiences. Therefore, despite the fact that these activities are strictly social in nature and that they occur in a relation with another person, in the offline world they are experienced alone.

9. Personal communication exhibiting characteristics of mass communication

Online relationships are characterised by sending each other very personal information and emotions. However, sending such communication is mediated by a network, which means that some messages can be saved in a virtual space forever.

10. Carnality without body

Cybersex is one of the online activities undertaken with a partner. Conversations are often accompanied by descriptions of the body or physical reactions.

Due to the characteristics of online relationships described above, as well as intimate activities occurring as part thereof, the characteristics of the emotional experiences of new generations is radically changing. For this reason, researchers decided to analyse this issue and create a scientific typology of online intimate relationships, with particular emphasis on the motivation of Internet users engaged in such relations.

Some people can be motivated to form an online relationship only for a shortlived romance, while others dream of finding somebody to love. Due to the di- 
versity of circumstances, the following types of intimate online relationships have been defined (Ben-Zeev, 2005):

1. relationships, the aim of which is to initiate relations online and then transfer them to real life;

2. relationships based on cyberflirting and cybersex (commonly referred to as "no-strings-attached" - not accompanied by any emotions);

3. emotional relationships in which the partners interact exclusively online (there is an emotional relationship between the partners, but they do not intend to transfer it to real life).

More and more often Internet users arrange "offline" dates using mobile applications. Interestingly enough, these meetings are not aimed at getting to know each other, talking, spending free time together in an interesting way, but rather at arranging a sexual intercourse. The first dating applications gained popularity in Poland in 2010. Nowadays, we are dealing with a concept of hook-ups, in the case of which feelings are marginalised. There are a lot of mobile dating apps, but Tinder, OkCupid and Hinge are the most popular. Some of them offer only user-submitted photos and some basic information. On this basis, another user decides on the attractiveness of a potential partner. The applications use the GPS signal to point to people who are relatively close to the user. (Ziomecka, 2015). Other applications of this kind, on the other hand, use tailor-made algorithms, which match people to each other on the basis of their answers to various questions (Szpunar, 2011).

In March 2017, the IRCenter research agency conducted a survey among Polish Internet users on Tinder in order to better understand people interested in this popular service. ${ }^{1}$ The agency made an attempt to profile them. During the year, $3.2 \%$ of Internet users in Poland used Tinder. They were usually men (55\%), aged between 18 and 24 (48\%), living in mid-sized and large towns and cities. Interestingly, not all users are lonely in real life. Only $54 \%$ of people declared that they were single, while $4 \%$ claimed that they were divorced or separated. As many as $22 \%$ declared that they were married and $19 \%$ that they had a partner. What is more, $30 \%$ of users also had children. Tinder users are usually ambitious, determined and open towards new experiences. They like change and are not afraid of challenges. They experiment with new trends and regularly check technological innovations (Niżnik, 2017). In spite of what it might look like, women are almost as interested in this dating app as men are. Most of the users are young people.

\footnotetext{
1 The survey was conducted using CAWI methodology on a representative group of 2100 Polish Internet users.
} 
This is all the more important because in order to create an account on Tinder, one needs to be at least 18 years old.

People who enter into relationships using dating services can especially celebrate their feelings during a special holiday - International Virtual Love Day, which is celebrated every year on July 24 th.

In the reality of constantly progressing digitalisation of social life, even the most private spheres of life are undergoing such transformations. This is particularly true for young people. The consequence of the growing popularity of mediated contacts in the context of building intimate relationships is disregarding the subjectivity of other people, which is manifested by the increasingly frequent occurrence of situations when the interpersonal attractiveness of a partner is decided by means of a mobile application. Such decisions are made impulsively, without deeper reflection, and the partner is chosen from among other random people on the list, which often resembles a "list of goods" arranged using techniques known to the marketers.

We may also consider the future of intimate relations between people and the place where they will occur. The main concern is the extent to which human sexuality can be transferred to virtual space and remain in it permanently. Two scenarios are possible in this respect. The first one assumes further expansion of the role of the Internet in establishing and maintaining emotional and erotic relationships. The other one, on the other hand, refers to a situation in which we will see a return to building direct relationships, not mediated by the media. It is also possible for the above scenarios to coexist in parallel. We might be dealing with growing popularity of mobile dating applications, similar to Tinder, which is currently the most popular mobile dating application, along with a growing number of alternatives to platforms offering a quick way to find a sexual partner with whom the user has no intention of establishing an emotional relationship.

\section{Bibliography}

Babecki M. (2010), Geneza pornografizacji przekazu w cyfrowej rozrywce krzemowych Kolumbów: przypadek Polski, Media - Kultura - Komunikacja Społeczna no. 6.

Beisert M. (2012), Rozwój seksualny dzieci i młodzieży, [in:] I. Namysłowska (ed.), Psychiatria dzieci i młodzieży, Warszawa.

Ben-Zeev A. (2005), Miłość w sieci. Internet i emocje, Poznań.

Bieńko M. (2011), Intymne strategie tożsamościowe dziecka we współczesnej kulturze popularnej, [in:] W. Jakubowski, S. Jaskulska (eds.), Kultura mediów, ciało i tożsamość, Kraków.

Janda-Dębek B., Kuczyńska A. (2006), Przyzwolenie na dotyk jako jeden z aspektów komunikacji międzyludzkiej a poziom samooceny, [in:] W.J. Maliszewski (ed.), Komunikowanie społeczne w edukacji. Dyskurs nad rola komunikowania, Toruń. 
Klimczyk W. (2008), Erotyzm ponowoczesny, Kraków.

Kozłowska A. (1993), Wpływ czynników biologicznych i psychicznych na czucie dotyku u dzieci, Przegląd Antropologiczny vol. 56, is. 1-2.

McNair B. (2001), Seks, demokratyzacja pożądania i media, czyli kultura obnażania, Warszawa.

Melosik Z. (2010), Tożsamość, ciało i władza w kulturze instant, Kraków.

Melosik Z. (2013), Kultura popularna i tożsamość młodzieży. W niewoli władzy i wolności, Kraków.

Nowosielski K. (2010), Cyberseksualność, [in:] Z. Lew-Starowicz (ed.), Podstawy seksuologii, Warszawa.

Osipczuk M., Hajek K., (2002), Ból seksoholika, http://www.psychotekst.pl/artykuly.php?nr=35, accessed: 23.04.2018.

Papież J. (2004), Cyberprzestrzeń a doznawanie przeżyć erotycznych, [in:] M. Sokołowski (ed.), Oblicza Internetu, Elbląg.

Pospiszyl I. (2008), Uzależnienia od stylu życia, [in:] W. Baturo (ed.), Katastrofy i zagrożenia we wspótczesnych świecie, Warszawa.

Sielicki J., (2017), Tinder - kim sa jego użytkownicy?, https://ircenter.com/tinder-kim-sa-jego-uzytkownicy/, accessed: 28.12.2017.

Szpunar W., (2011), Portale matrymonialne na świecie, http://www.pcworld.pl/news/Portale-matrymonialne-na-swiecie,372154.html, accessed: 28.12.2017.

Waszyńska K. (2015), W (nie)rzeczywistej relacji z innymi, czyli miłość i seks w cyberprzestrzeni, Studia Edukacyjne no. 34.

Wójtewicz A. (2009), Społeczno-kulturowy i historyczny kontekst interpretacyjny zjawiska seksualizacji, definicje i inspiracje badawcze, [in:] K. Stadnik, A. Wójtewicz (eds.), Anielice czy diablice?, Warszawa.

ZiomeckaZ.,(2015),JakTinderzmieniakulturęrandkowaniawseksustawki,http://www.wysokieobcasy. pl/wysokie-obcasy/1,115167,18545585,jak-tinder-zmienia-kulture-randkowania-w-seks-ustawki.html, accessed: 28.12.2017. 